\title{
Prevalence of transcription factors in ascomycete and basidiomycete fungi
}

\author{
Richard B Todd ${ }^{1 *}$, Miaomiao Zhou ${ }^{2+}$, Robin A Ohm ${ }^{3,4}$, Hendrika ACF Leeggangers ${ }^{2,5}$, Loek Visser ${ }^{3}$ \\ and Ronald P de Vries ${ }^{2,3}$
}

\begin{abstract}
Background: Gene regulation underlies fungal physiology and therefore is a major factor in fungal biodiversity. Analysis of genome sequences has revealed a large number of putative transcription factors in most fungal genomes. The presence of fungal orthologs for individual regulators has been analysed and appears to be highly variable with some regulators widely conserved and others showing narrow distribution. Although genome-scale transcription factor surveys have been performed before, no global study into the prevalence of specific regulators across the fungal kingdom has been presented.
\end{abstract}

Results: In this study we have analysed the number of members for 37 regulator classes in 77 ascomycete and 31 basidiomycete fungal genomes and revealed significant differences between ascomycetes and basidiomycetes. In addition, we determined the presence of 64 regulators characterised in ascomycetes across these 108 genomes. This demonstrated that overall the highest presence of orthologs is in the filamentous ascomycetes. A significant number of regulators lacked orthologs in the ascomycete yeasts and the basidiomycetes. Conversely, of seven basidiomycete regulators included in the study, only one had orthologs in ascomycetes.

Conclusions: This study demonstrates a significant difference in the regulatory repertoire of ascomycete and basidiomycete fungi, at the level of both regulator class and individual regulator. This suggests that the current regulatory systems of these fungi have been mainly developed after the two phyla diverged. Most regulators detected in both phyla are involved in central functions of fungal physiology and therefore were likely already present in the ancestor of the two phyla.

Keywords: Transcription factor, Ascomycete, Basidiomycete, Gene regulation, Fungal genomes, Evolution, Zinc binuclear cluster, Zinc finger, DNA binding domain, Aspergillus

\section{Background}

Gene regulation is of major importance for physiology of all organisms, and has been intensively studied in fungi. It ensures that the required genes are switched on and act under the circumstances they are needed, and allows fungi to respond to changing conditions. Thirty-seven classes of regulator proteins have been identified in fungi [1], such as C2H2 (PF00096) [2], Zn2Cys6 (PF00172) [3], Fungal Specific transcription factor domain (PF04082), bZIP (PF00170) [4], Histone-like transcription factors (PF00808) [5], HLH (PF00010) [6], HSF (PF00447) [7],

\footnotetext{
* Correspondence: rbtodd@k-state.edu

${ }^{\dagger}$ Equal contributors

'Department of Plant Pathology, Kansas State University, 4024 Throckmorton Plant Sciences Center, Manhattan, KS 66506, USA

Full list of author information is available at the end of the article
}

Myb DNA-binding (PF00249) [8], TEA (PF01285) [9] and GATA (PF00320) [10]. They coordinate many cellular processes that control growth, survival or reproduction on particular substrates, under certain conditions, or in particular environmental niches. Therefore the presence or absence of specific regulators is intimately linked to fungal biodiversity.

Analysis of the first available eukaryotic genome indicated a likely diversity of regulators [11]. For example, a number of Zn2Cys6 regulators known in other fungi were absent in Saccharomyces cerevisiae [12]. Differences in regulatory protein repertoire were found particularly for this class of regulators, which was reduced in number in Kluyveromyces lactis compared with S. cerevisiae [13], and considerably expanded in Aspergillus nidulans [14] and Magnaporthe oryzae [15]. Furthermore, a range of

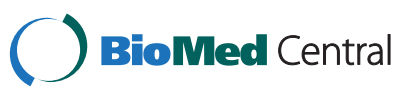


functions for fungal Zn2Cys6 regulators lacking yeast orthologs have been described [16]. With an exponentially growing number of fungal genome sequences covering all branches of the fungal tree of life it is now possible to explore the regulatory diversity of fungi and trace the evolutionary origin of particular regulators. For several specific regulators their presence in sets of fungal genomes has been reported. The pentose catabolic pathway in Aspergillus is regulated by two transcriptional activators, $\mathrm{X} \ln \mathrm{R}$ and AraR [17]. While XlnR is present in nearly all tested filamentous ascomycetes, AraR appears to be restricted to the order of the Eurotiales that consists of Aspergillus, Penicillium and related genera. An even higher diversity was observed for regulators of galactose catabolism. A subset of the ascomycetes contains the regulator GalX that appears to be mainly involved in the oxidoreductive pathway in Aspergillus niger and A. nidulans $[18,19]$. In addition, $A$. nidulans contains a second regulator, GalR, that controls genes of the Leloir Pathway and for which orthologs were not detected in any of the other studied species [18]. The A. nidulans long chain fatty acid utilisation regulators FarA and FarB, which themselves are related in sequence, each have orthologs widely conserved in filamentous fungi and share a single common homolog in certain Hemiascomycetes [20]. In contrast, the short chain fatty acid utilisation regulator ScfA was very poorly conserved, with possible orthologs in A. nidulans, Aspergillus fumigatus and Neurospora crassa [20]. The A. niger extracellular protease regulator PrtT was identified only in certain Aspergilli [21].

Previous genome-wide studies of transcription factors have focussed on a single transcription factor family $[12,22,23]$, a single species [24], or the relative representation of transcriptional regulator classes in the fungal kingdom [1,25]. The rapid growth in availability of fungal genomes, particularly those of Basidiomycetes, over the last few years has now yielded wider representation of genome sequence data across the various lineages of the fungal kingdom and provides the opportunity for a more detailed analysis of prevalence of transcription regulators across fungal genomes. In this paper we compared the distribution of regulator gene classes between currently available fungal genomes. We analysed the presence or absence of 64 characterised regulators in 108 fungal genomes to provide a comprehensive evaluation of fungal diversity with respect to regulatory systems. The regulators we have focussed on are all well characterised in at least one fungal species and represent a range of different physiological functions, including 21 regulators involved in development and/or morphology, 19 regulators involved in carbon metabolism, and 13 regulators involved in nitrogen and amino acid metabolism. Many of these regulators perform central functions in the organisms where they have been initially studied and therefore provide a good test set for the analysis of their prevalence and evolution in the fungal kingdom.

\section{Results \\ Distribution of regulator classes throughout the fungal kingdom}

To determine whether there are major differences in the relative number of regulators from different classes in the different fungal phyla, a PFAM analysis of the 37 known fungal transcription regulator-related PFAM domains [1] was performed on 77 ascomycete and 31 basidiomycete genomes (Additional file 1). A total of 36,636 putative transcription factors were identified (Additional file 2). Interesting differences in the relative number of regulators from different PFAM classes could be observed between the two phyla (Figure 1, Additional file 3). When comparing Ascomycota and Basidiomycota the main differences are a much larger expansion of the Zn2Cys6 domain family (PF000172) and the fungal specific transcription factor domain proteins (PF04082) in the Ascomycota, while in the Basidiomycota the $\mathrm{C} 2 \mathrm{H} 2$ family (PF00096) and the $\mathrm{CCHC}$ zinc-finger family (PF00098) form a significantly higher percentage of the total number of regulators (Figure 1). This indicates that after these phyla split different regulatory strategies have developed based on different regulator classes. Within the Ascomycota, pezizomycetes contained the highest average amount (450) of putative regulators compared to saccharomycetes (210) and taphrinomycetes (122). Moreover, the Zn2Cys6 domain family and fungal specific transcription factor domain proteins in pezizomycotina were found in higher proportions than in the saccharomycotina and taphrinomycotina indicating the major expansion of these regulator classes occurred after divergence of the pezizomycotina from the other lineages. Unlike in the Basidiomycota, the lower abundance of these two families in the saccharomycotina and taphrinomycotina is not accompanied with a higher abundance of the $\mathrm{C} 2 \mathrm{H} 2$ and CCHC families.

To compare the PFAM distribution of transcription factors between different fungal species, we used hierarchical clustering. The 36,636 regulators identified in the PFAM analysis were clustered, using OrthoMCL followed by manual curation, into 2,887 non-redundant orthologous groups (Additional file 4). These ortholog groups were then used to analyze the distribution of putative regulators among the PFAM families in fungi. A clear trend of regulator family distribution could be detected when species were clustered based on the transcription factor abundance pattern of the families (Figure 2). Interestingly, within Ascomycota only pezizomycotina species were clustered as one distinct group, the other major subdivisions, saccharomycotina and taphrinomycotina, were clustered within the Basidiomycota as two 
A

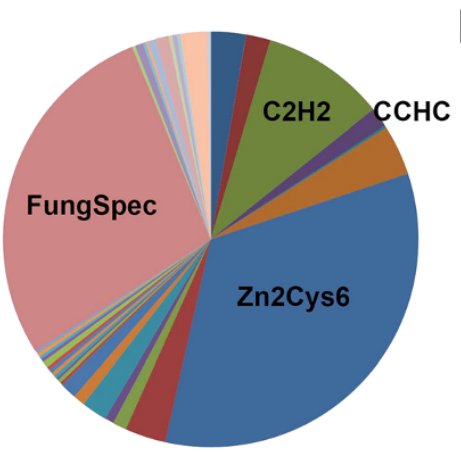

366 (76)

—PF00010 चPF00046 —PF00096

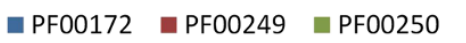

-PF00989 =PF01285 =PF01381

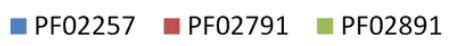

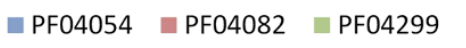

$\square \mathrm{PF} 05224 \square \mathrm{PF} 05225 \square \mathrm{PF} 05764$
$\square \mathrm{PF} 07975$

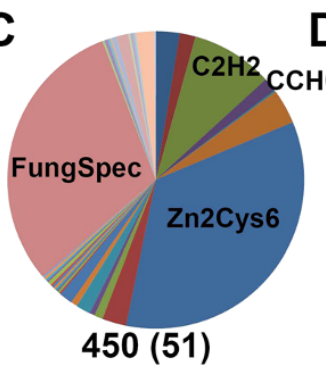

B

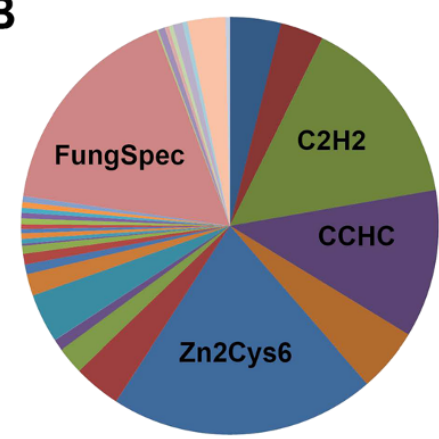

283 (31)

aPF00165 —PF00170

nPF00320 —PF00447

- PF02045 —PF02200

—PF02928 $\square$ PF03343

—PF04516 PF04769

—PF07093 —PF07716

D $E$

E
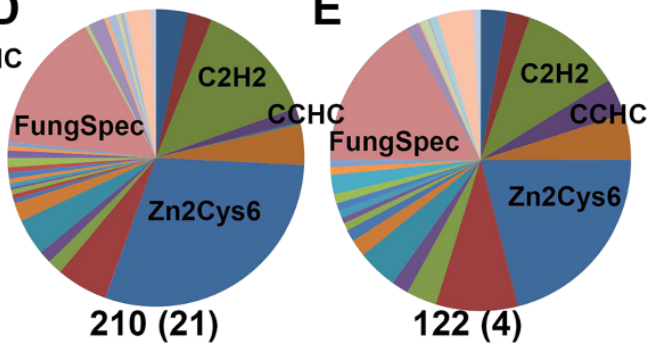

Figure 1 Relative distribution of regulator PFAM family members in different fungal phyla. A: ascomycetes, B: basidiomycetes, C: pezizomycotina; D: saccharomycotina; E: taphrinomycotina. The description of the PFAM families can be found in Additional file 3. The average number of transcription factors for each phylum is indicated underneath each pie chart. The number of genomes analyzed in each phylum or subphylum is indicated in parentheses.

separate groups next to agaricomycotina. This indicates that after these phyla diverged, different regulator classes have been exploited in different lineages.

\section{Prevalence of specific regulators in fungal genomes}

A pilot study using bidirectional BlastP analysis to identify putative orthologs of a subset of chosen regulators was performed followed by manual curation to determine the parameters for automated analysis of the prevalence of regulators in fungal genomes (data not shown). This automated analysis was used to test for the presence or absence of orthologs of 64 regulators (Additional file 5) in the 108 genomes used for the PFAM distribution analysis above (Additional file 6, Additional file 7). A cut-off designated for identification of distant homologs [26] was applied throughout the survey in order to decrease the false negative rate caused by the highly divergent sequences of regulators. The results were then manually curated based on sequence alignments and phylogeny to remove false positives. An example is presented for AraR, where GalR was identified as a false positive (Figure 3).

Although the lowest number of orthologs was identified in the Basidiomycota, orthologs for five regulators involved in development and/or morphology (DopA, SteA, RlmA, MedA, Con7), the carbon catabolite repressor $\mathrm{CreA}$, and the general expression activators HapB, HapC and HapE, are commonly found in basidiomycetes. Most of these regulators have general functions for fungal physiology, which explains their common distribution among fungi. Conversely, orthologs for six of the seven regulators from Schizophyllum commune (Fts3, Fts4, Hom1, Hom2, Gat1, C2H2) were only detected in basidiomycetes, while the other (WC2) also had orthologs in filamentous ascomycetes. Interestingly, no basidiomycete orthologs were detected for any of the transcriptional activators involved in plant biomass utilization (XlnR, AmyR, InuR, AraR, GalR, GalX, RhaR). All these regulators are members of the Zn2Cys6 class (Additional file 5), which is particularly expanded in 


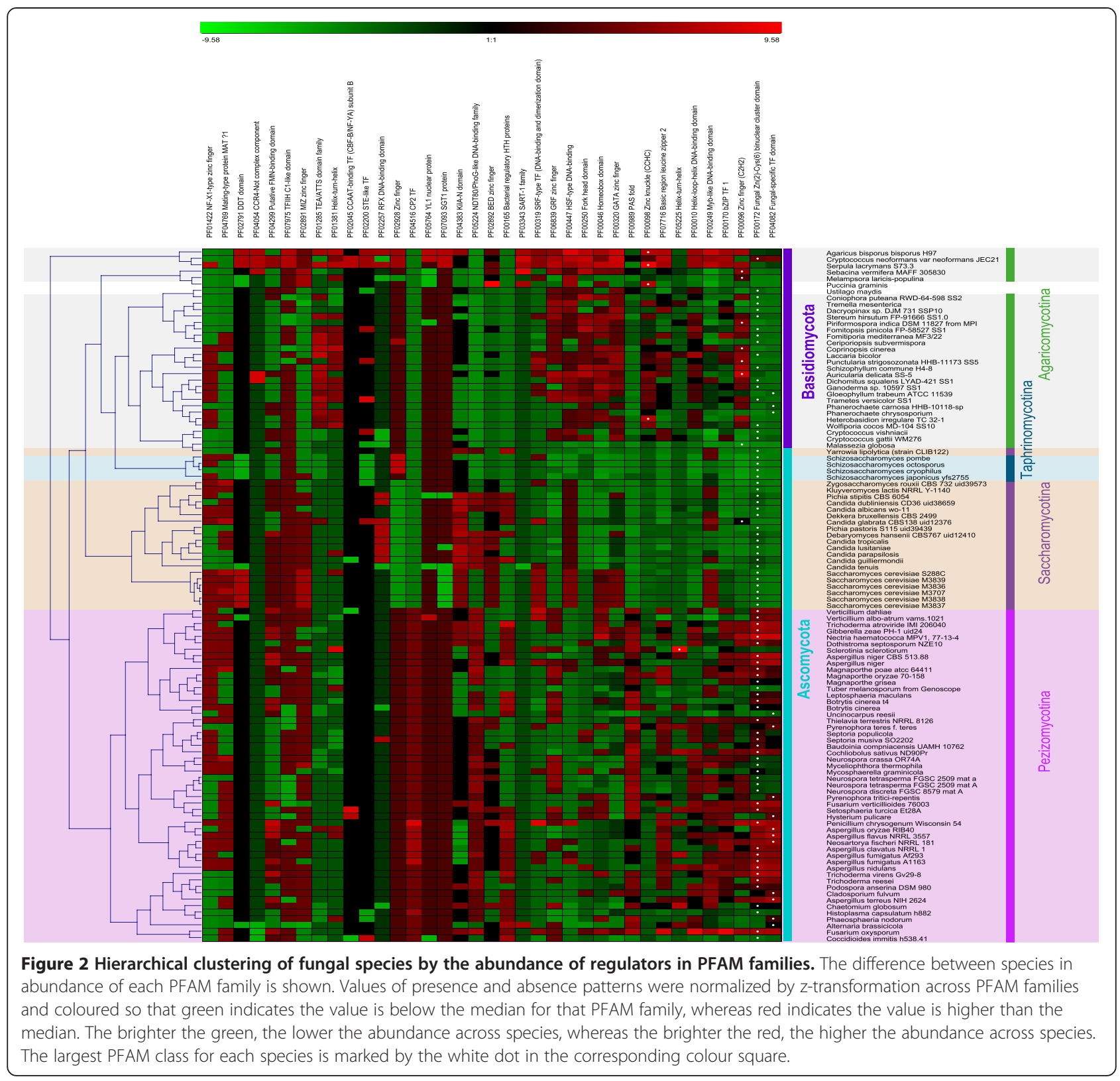

ascomycetes compared to basidiomycetes (Figure 1). Indications for similar regulation systems related to plant biomass degradation have been found in transcriptomics studies of basidiomycetes [27-33]. However, the absence of orthologs for the ascomycete regulators suggests that these regulators have developed after the split from the ascomycetes, and the underlying molecular mechanisms may differ.

The overall low number of regulators for which an ortholog could be found in the basidiomycetes fits with the general PFAM distribution (see above) in which clear differences were found in the expansion of the different PFAM families between ascomycetes and basidiomycetes. This suggests a smaller regulatory repertoire in the ancestral fungus, which has undergone significant evolution since the basidiomycetes and ascomycetes separated.

The ascomycete yeast genomes also lack a significant number of the regulators, in particular those involved in plant biomass degradation and those involved in development. As most yeasts are not able to degrade plant biomass, nor go through developmental changes, this fits well with their physiology. Interestingly, there is a division into two groups with respect to the presence of CreA orthologs. Saccharomyces lacks this regulator, but instead has MIG1, which is the functional homolog of CreA, despite low sequence similarity. MIG1 orthologs were not found in any of the other tested fungi (Additional file 7). 


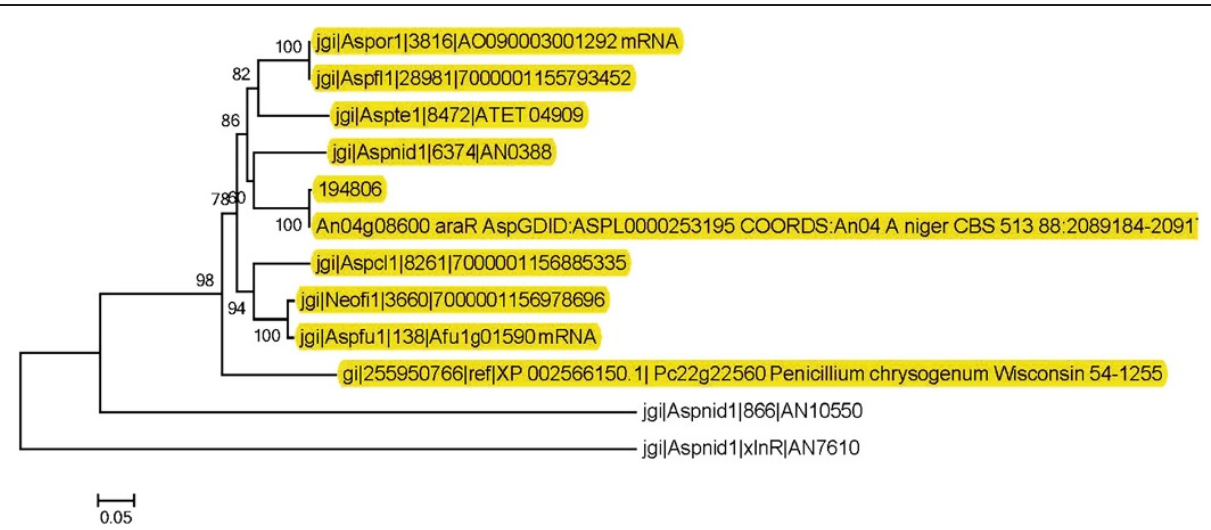

Figure 3 Example of phylogenetic identification of false orthologs. Neighbor-Joining tree of the AraR homologs using Aspergillus nidulans XInR as an outgroup. The genes marked in yellow were maintained in the comparison. AN10550 was manually removed, as it clearly did not fall into the same cluster as the other genes. In fact, this gene is GalR, which is unique to A. nidulans. The gene identifiers can be found in Additional file 7.

The most diverse profiles can be seen for the filamentous ascomycetes. Regulators that are particularly poorly conserved in this group include two involved in development and/or morphology (AbaA, BrlA, mainly limited to Aspergilli and Penicillium), seven involved in carbon metabolism (AraR, GalX, GalR, ScfA, InuR, AlcR, AceII), one involved in nitrogen metabolism (AmdR), the iron homeostasis regulator SreA, the unfolded protein response regulator HacA and the aflatoxin biosynthesis regulator AflR, but many other differences can be observed. While the presence of some of these regulators appears to be evolutionarily related (present in nearly all species of a certain fungal clade) others are more dispersed through the ascomycete tree of life, suggesting that the regulator was present in their common ancestor but has been lost in specific species of different lineages.

Present in nearly all of the filamentous Ascomycetes (with a cut-off of three genomes missing the regulator) are eleven regulators involved in development and/or morphology (DopA, RosA, SteA, RlmA, MedA, DevR, Hsf2, Con7, StuA, WC2, VeA), four involved in carbon metabolism (FacB, FarB, AceI, AmdX), seven involved in nitrogen metabolism (UaY, LeuB, CpcA, NirA, AreB alpha, Nut1, NmrA), the His-Asp phosphorylation signalling regulator SrrA, the CCAAT-binding complex components HapB, HapC and HapE, the sulphur metabolic regulator MetR, and the penicillin biosynthesis regulator PenR2, providing a core set of transcriptional regulators that control most aspects of physiology.

For some transcription factors, multiple homologs were identified in the same species. In those cases where manual curation did not allow elimination of the additional copies, they were retained in the output data set (Additional file 3, Additional file 4, Additional file 6 and Additional file 7). We do not assume that the different copies will have the same function, although they are likely involved in similar processes. Functional analysis of these proteins will be needed to reveal their biological role.

\section{Discussion}

Genomic studies of fungal transcription regulators have generally focused on a single transcription factor class in a particular species (e.g. [12,22,23]), or on the transcription factor complement within one species (e.g. [15,23]). However, analyses of transcription factor families have been conducted across a range of fungal genomes $([1,25])$. One study identified 37 PFAM families of transcription factors represented in 62 fungal genomes, and revealed the Zn2Cys6 zinc binuclear cluster and the fungal-specific transcription factor domain as the two largest fungal transcription factor classes [1]. Another study focussed on identification of transcription factors in 62 fungal genomes using the Fungal Transcription Factor Database (FTFD) phylogenomics pipeline, and determined the proportion of transcription factors amongst total predicted proteins [25]. Analysis of transcription factor family distribution revealed species-specific differences [25]. The aim of our study was to perform an inventory of the presence of regulators in the fungal kingdom, employing the expanded set of genome sequences that have become available in the last five years. Our analysis of the distribution of regulator classes indicated differential expansion of certain regulator types in ascomycetes and basidiomycetes, consistent with the development of many regulatory systems from a more limited ancestral set of regulators after the divergence of the two major fungal phyla. In ascomycetes, the $\mathrm{Zn} 2 \mathrm{Cys} 6$ and fungal-specific domain regulators overwhelmingly predominated. This is consistent with previous identification of these two regulator classes as the most abundant fungal-specific regulators in a smaller set of mostly ascomycete fungal genomes [1]. The $\mathrm{C} 2 \mathrm{H} 2$ zinc finger class comprised a smaller but major regulator class in the ascomycetes. Further analysis revealed a greater 
relative abundance of the Zn2Cys6 and fungal-specific domain regulators in the pezizomycotina than in the saccharomycotina and taphrinomycotina. In basidiomycetes, the $\mathrm{C} 2 \mathrm{H} 2$ and $\mathrm{CCHC}$ classes showed a relative expansion and, with the Zn2Cys6 and fungal-specific domain regulators, comprise four similarly abundant major regulator classes. The differential expansion of regulator families in the fungal phyla and sub-phyla suggests that evolution of many regulators occurred after the divergence of these groups. The regulator distribution observed in our analysis showed some differences compared with the previously reported distributions in FTFD [25], most likely due to our expanded dataset. However, the abundance of $\mathrm{Zn} 2 \mathrm{Cys} 6$ and $\mathrm{C} 2 \mathrm{H} 2$ domain regulators reported in FTFD are compatible with our results.

As regulators play a major role in fungal physiology, their presence or absence may provide options and impose limitations on the natural habitat of fungal species. Analysis of the presence of individual transcription factors demonstrated that regulators with a central role in fungal physiology are most commonly found throughout the fungal tree of life, while regulators with more specific roles are less commonly present. This makes sense, as the loss of central regulators is likely to cause a significant competitive disadvantage for a species, unless transcriptional network functions are maintained by transcriptional rewiring. In contrast, the more specific regulators and the regulons they control will only be essential or advantageous in particular habitats.

As the characterised query regulators for our transcription factor presence/absence analysis were mainly from ascomycete fungi, it is not surprising that a relatively low number of orthologs was found in the genomes from basidiomycetes. Regulation of gene expression is poorly studied in these fungi compared with ascomycetes, but our data suggests that many of the regulatory systems have developed after the split of these two phyla. Interestingly, differences in the presence and absence of regulators were also found in closely related species. While it cannot be fully excluded that this can be due to gaps in the genome sequence or errors in gene annotation of specific genomes, this does suggest that changes in the regulatory systems have also occurred more recently. Examples of this are the GalX/GalR system for regulation of galactose catabolism [18] and the protease regulator PrtT [21], which was shown to differ significantly between the Aspergilli, and the specific presence of the cellulose regulator AceII [34].

While the absence of a particular regulator may accompany loss of an entire regulon and therefore an altered metabolic or developmental capability, its absence could indicate transcriptional rewiring of the regulatory mechanism. Conversely, presence of a regulator ortholog also does not necessarily indicate conserved function.
Recent studies have shown that transcription regulatory mechanisms can display considerable plasticity across species. For some regulons the regulator components are conserved but exhibit functional reassignment and rewired circuitry, resulting in rearrangements of transcriptional networks [35]. Other regulons share a conserved overall strategy but include additional regulator components to integrate additional regulatory signals, or show transfer of regulation from one regulator to another, or rewiring via evolution of combinatorial interactions between transcription factors [36-38]. The array of transcriptional rewiring possibilities indicates that while the absence of a particular transcription factor ortholog suggests regulatory differences or the loss of regulons, the presence of orthologs may, but does not necessarily indicate conserved function. Therefore functional analysis is required to determine the role of each transcription factor in each species.

\section{Conclusion}

We have conducted an inventory of the thirty-seven PFAM transcription factor classes across 108 genomes of the two major fungal phyla and shown differential expansion of transcription regulator classes between the ascomycetes and the basidiomycetes, with the largest expansion of $\mathrm{Zn} 2 \mathrm{Cys} 6$ and fungal-specific domain regulators in the pezizomycotina. We also analyzed the presence profiles for 64 known regulators in these 108 genomes and found that regulators with central functions in fungal physiology were more commonly present than those with more specialised roles. The increasing number of fungal genome sequences and functional analyses will provide better insight in the evolution of regulatory systems and in particular the 1000 fungal genome project [39] will add to this as it aims to cover the breadth of the fungal kingdom.

\section{Methods}

\section{Pilot experiment}

A bidirectional BlastP analysis was performed using as query the amino acid sequences of 48 selected regulators. To manually curate the results, alignments of the hits for each query regulator were performed using MUSCLE [40] and manually corrected in MEGA4 [41]. Phylogenetic trees were generated with MEGA4 using three algorithims: Maximum Parsimony, neighbor joining and minimum evolution. The stability of the clades was tested with 1000 bootstrap replicates. The results of the manual curation were used to define the parameters for the automated analysis of a larger set of genomes.

\section{Large-scale genome study}

108 completed fungal genomes were extracted from the JGI fungal program [42], Broad Institute of Harvard and 
MIT [43], AspGD [44,45] and NCBI genbank [46] (data version March 2013). Pfam-A HMM model was downloaded from the Pfam database [47]. Regulator-related domains were identified in each fungal genome in HMMerv. 3.0 [48] using the trust cutoff. Genome scale protein ortholog clusters were detected according to [49], using inflation factor $1, \mathrm{E}$-value cutoff $1 \mathrm{E}-3$, percentage match cutoff $60 \%$ as for identification of distant homologs [26]. The all-vs-all BlastP search required by OrthoMCL was carried out in a grid of 500 computers by parallel fashion. The orthologs clusters were then curated manually by expert knowledge and literature search. Manual curation was aided by aligning the amino acid sequences of the hits for each query together with a suitable outgroup by MAFFT [50,51], after which neighbor joining trees were generated using MEGA5 with 1000 bootstraps. Genes that were clearly separated from the query branch in the trees were removed from the results. An example of this is given for AraR in Figure 3. Putative regulators containing more than one PFAM domain were assigned to the cluster based on the number of copies of domains found and/or the length of aligned area to the domain. PFAM families in 108 genomes were clustered by mismatch distance using Genesis [52]. The dendrogram was drawn by the complete linkage method using Genesis. A z-transformation of data was performed across families in order to generate the color scheme for visualization.

\section{Availability of supporting data}

The data sets supporting the results of this article are included within the article and its additional files, or are available in the Dryad Digital Repository [53].

\section{Additional files}

Additional file 1: Fungal genomes used in this study. Species, genome sequence file name, phylogenetic division, source of genome sequence data, and reference [54-104].

Additional file 2: Putative regulators identified by Pfam in 108 fungal genomes.

Additional file 3: Distribution of numbers of putative regulator encoding genes per PFAM family in different fungi. The number of regulators in each PFAM class found in each of the 108 genomes analysed.

Additional file 4: The orthologous clusters of putative regulators in 108 fungi. Gene ID of all 36,636 putative transcriptional factors clustered in 2,887 non-redundant orthologous groups.

Additional file 5: Regulators used in this study Transcription factor, family, process/function, species, and reference [9,17,18,20,21,34,105-152].

Additional file 6: Presence of homologs of the 64 selected regulators in 108 fungal genomes. Presence or absence of homologs of each regulator are tabulated for the 108 fungal genomes analysed.

Additional file 7: Gene IDs of the homologs of the 64 regulators. Gene IDs are displayed as indicated in the genome downloads. In the case of mutiple homologs, the gene ID's are in the same cell separated by a comma.

The authors declare that they have no competing interests.

\section{Authors' contributions}

RAO performed the genome mining for the pilot experiment, while MZ performed the large scale genome mining. HACFL and LV performed manual curation on the pilot experiment. RBT and RPdV designed the study. RBT, RPdV and MZ wrote the manuscript. All authors contributed to the interpretation of the data. RBT and MZ contributed equally. All authors read and approved the final manuscript.

\section{Acknowledgements}

MZ was supported by a grant from the Netherlands Organisation for Scientific Research (NWO) and the Netherlands Genomics Initiative 93511035 to RPdV. The large scale genome mining was carried out on the Dutch nationa e-infrastructure with the support of SURF Foundation (e-infra130078). Contribution No. 14-055-J from the Kansas Agricultural Experiment Station (RBT).

\section{Author details}

'Department of Plant Pathology, Kansas State University, 4024 Throckmorton Plant Sciences Center, Manhattan, KS 66506, USA. ²Fungal Physiology, CBS-KNAW, Uppsalalaan 8, 3584 CT Utrecht, The Netherlands. ${ }^{3}$ Microbiology \& Kluyver Centre for Genomics of Industrial Fermentations, Utrecht University, Uppsalalaan 8, 3584 CT Utrecht, The Netherlands. ${ }^{4}$ Current address: US Department of Energy (DOE) Joint Genome Institute (JGI), 2800 Mitchell Drive, Walnut Creek, CA 94598, USA. ${ }^{5}$ Current address: Department of Plant Physiology, Wageningen University, Droevendaalsesteeg 1, 6708 PA, Wageningen, The Netherlands.

Received: 17 August 2013 Accepted: 11 March 2014

Published: 20 March 2014

\section{References}

1. Shelest E: Transcription factors in fungi. FEMS Microbiol Lett 2008, 286:145-151.

2. luchi S: Three classes of $\mathrm{C} 2 \mathrm{H} 2$ zinc finger proteins. Cell Mol Life Sci 2001, 58:625-635

3. Pan T, Coleman JE: GAL4 transcription factor is not a "zinc finger" but forms a Zn(II)2Cys6 binuclear cluster. Proc Natl Acad Sci USA 1990, 87:2077-2081.

4. Hurst HC: Transcription factors 1: bZIP proteins. Protein Profile 1995, 2:101-168.

5. Burley SK, Xie X, Clark KL, Shu F: Histone-like transcription factors in eukaryotes. Curr Opin Struct Biol 1997, 7:94-102.

6. Littlewood TD, Evan Gl: Transcription factors 2: helix-loop-helix. Protein Profile 1995, 2:621-702

7. Clos J, Westwood JT, Becker PB, Wilson S, Lambert K, Wu C: Molecular cloning and expression of a hexameric Drosophila heat shock factor subject to negative regulation. Cell 1990, 63:1085-1097.

8. Aasland R, Stewart AF, Gibson T: The SANT domain: a putative DNA-binding domain in the SWI-SNF and ADA complexes, the transcriptional co-repressor N-CoR and TFIIIB. Trends Biochem Sci 1996, 21:87-88

9. Andrianopoulos A, Timberlake WE: ATTS, a new and conserved DNA binding domain. Plant Cell 1991, 3:747-748.

10. Scazzocchio C: The fungal GATA factors. Curr Opin Microbio/ 2000, 3:126-131.

11. Goffeau A, Barrell BG, Bussey H, Davis RW, Dujon B, Feldmann H, Galibert F, Hoheisel JD, Jacq C, Johnston M, Louis EJ, Mewes HW, Murakami Y, Philippsen P, Tettelin H, Oliver SG: Life with 6000 genes. Science 1996, 274:546-547.

12. Todd RB, Andrianopoulos A: Evolution of a fungal regulatory gene family: the Zn(II)2Cys6 binuclear cluster DNA binding motif. Fungal Genet Biol 1997, 21:388-405.

13. Bussereau F, Casaregola S, Lafay JF, Bolotin-Fukuhara M: The Kluyveromyces lactis repertoire of transcriptional regulators. FEMS Yeast Res 2006, 6:325-335.

14. Wortman JR, Gilsenan JM, Joardar V, Deegan J, Clutterbuck J, Andersen MR, Archer D, Bencina M, Braus G, Coutinho P, von Dohren H, Doonan J, Driessen AJ, Durek P, Espeso E, Fekete E, Flipphi M, Estrada CG, Geysens S, Goldman G, de Groot PW, Hansen K, Harris SD, Heinekamp T, Helmstaedt K, Henrissat B, Hofmann G, Homan T, Horio T, Horiuchi H, et al: The 2008 update of the Aspergillus nidulans genome annotation: a community effort. Fungal Genet Biol 2009, 46(Suppl 1):S2-S13.

15. Park S-Y, Choi J, Lim S-E, Lee G-W, Park J, Kim Y, Kong S, Kim SR, Rho H-S, Jeon J, Chi M-H, Kim S, Khang CH, Kang S, Lee Y-H: Global expression profiling of transcription factor genes provides new insights into 
pathogenicity and stress responses in the rice blast fungus. PLoS Pathog 2013, 9:e1003350.

16. MacPherson $\mathrm{S}$, Larochelle $\mathrm{M}$, Turcotte $\mathrm{B}$ : A fungal family of transcriptional regulators: the zinc cluster proteins. Microbiol Mol Biol Rev 2006, 70:583-604

17. Battaglia E, Visser L, Nijssen A, van Veluw J, Wösten HAB, de Vries RP. Analysis of regulation of pentose utilisation in Aspergillus niger reveals evolutionary adaptations in the Eurotiales. Stud Mycol 2011, 69:31-38.

18. Christensen U, Gruben BS, Madrid S, Mulder H, Nikolaev I, de Vries RP: Unique regulatory mechanism for D-galactose utilization in Aspergillus nidulans. Appl Environ Microbiol 2011, 77:7084-7087.

19. Gruben BS, Zhou M, de Vries RP: GalX regulates the D-galactose oxidoreductive pathway in Aspergillus niger. FEBS Lett 2012, 586:3980-3985.

20. Hynes MJ, Murray SL, Duncan A, Khew GS, Davis MA: Regulatory genes controlling fatty acid catabolism and peroxisomal functions in the filamentous fungus Aspergillus nidulans. Eukaryot Cell 2006, 5:794-805.

21. Punt PJ, Schuren FH, Lehmbeck J, Christensen T, Hjort C, van den Hondel CA: Characterization of the Aspergillus niger prtT, a unique regulator of extracellular protease encoding genes. Fungal Genet Bio 2008, 45:1591-1599.

22. Colot HV, Park G, Turner GE, Ringelberg C, Crew CM, Litvinkova L, Weiss RL, Borkovich KA, Dunlap JC: A high-throughput gene knockout procedure for Neurospora reveals functions for multiple transcription factors. Proc Natl Acad Sci USA 2006, 103:10352-10357.

23. Tian C, Li J, Glass NL: Exploring the bZIP transcription factor regulatory network in Neurospora crassa. Microbiology 2011, 157:747-759.

24. Son H, Seo YS, Min K, Park AR, Lee J, Jin JM, Lin Y, Cao P, Hong SY, Kim EK, Lee SH, Cho A, Lee S, Kim MG, Kim Y, Kim JE, Kim JC, Choi GJ, Yun SH, Lim JY, Kim M, Lee YH, Choi YD, Lee YW: A phenome-based functional analysis of transcription factors in the cereal head blight fungus, Fusarium graminearum. PLoS Pathog 2011, 7:e1002310.

25. Park J, Jang S, Kim S, Kong S, Choi J, Ahn K, Kim J, Lee S, Park B, Jung K, Kang S, Lee YH: FTFD: an informatics pipeline supporting phylogenomic analysis of fungal transcription factors. Bioinformatics 2008, 24:1024-1025.

26. Boekhorst J, Snel B: Identification of homologs in insignificant blast hits by exploiting extrinsic gene properties. BMC Bioinformatics 2007, 8:356

27. Macdonald J, Doering M, Canam T, Gong Y, Guttman DS, Campbell MM, Master ER: Transcriptomic responses of the softwood-degrading white-rot fungus Phanerochaete carnosa during growth on coniferous and deciduous wood. Appl Environ Microbiol 2011, 77:3211-3218.

28. MacDonald J, Suzuki H, Master ER: Expression and regulation of genes encoding lignocellulose-degrading activity in the genus Phanerochaete. Appl Microbiol Biotechnol 2012, 94:339-351.

29. Martinez D, Challacombe J, Morgenstern I, Hibbett D, Schmoll M, Kubicek CP. Ferreira P, Ruiz-Duenas FJ, Martinez AT, Kersten P. Hammel KE, Vanden Wymelenberg A, Gaskell J, Lindquist E, Sabat G, Bondurant SS, Larrondo LF, Canessa P, Vicuna R, Yadav J, Doddapaneni H, Subramanian V, Pisabarro AG, Lavin JL, Oguiza JA, Master E, Henrissat B, Coutinho PM, Harris P, Magnuson $J \mathrm{~K}$, et al: Genome, transcriptome, and secretome analysis of wood decay fungus Postia placenta supports unique mechanisms of lignocellulose conversion. Proc Natl Acad Sci USA 2009, 106:1954-1959.

30. Sato $S$, Feltus FA, lyer $P$, Tien M: The first genome-level transcriptome of the wood-degrading fungus Phanerochaete chrysosporium grown on red oak. Curr Genet 2009, 55:273-286.

31. Vanden Wymelenberg A, Gaskell J, Mozuch M, Kersten P, Sabat G, Martinez D, Cullen D: Transcriptome and secretome analyses of Phanerochaete chrysosporium reveal complex patterns of gene expression. Appl Environ Microbiol 2009, 75:4058-4068.

32. Vanden Wymelenberg A, Gaskell J, Mozuch M, Sabat G, Ralph J, Skyba O, Mansfield SD, Blanchette RA, Martinez D, Grigoriev I, Kersten PJ, Cullen D: Comparative transcriptome and secretome analysis of wood decay fungi Postia placenta and Phanerochaete chrysosporium. Appl Environ Microbiol 2010, 76:3599-3610

33. Vanden Wymelenberg A, Gaskell J, Mozuch M, BonDurant SS, Sabat G, Ralph J, Skyba O, Mansfield SD, Blanchette RA, Grigoriev IV, Kersten PJ, Cullen D: Significant alteration of gene expression in wood decay fungi Postia placenta and Phanerochaete chrysosporium by plant species. Appl Environ Microbiol 2011, 77:4499-4507.

34. Aro N, Saloheimo M, IImén M, Penttilä M: ACEll, a novel transcriptional activator involved in regulation of cellulase and xylanase genes of Trichoderma reesei. J Biol Chem 2001, 276:24309-24314.
35. Lavoie $\mathrm{H}$, Hogues $\mathrm{H}$, Whiteway M: Rearrangements of the transcriptional regulatory networks of metabolic pathways in fungi. Curr Opin Microbiol 2009, 12:655-663.

36. Booth $L N$, Tuch BB, Johnson AD: Intercalation of a new tier of transcription regulation into an ancient circuit. Nature 2010, 468:959-963.

37. Li H, Johnson AD: Evolution of transcription networks-lessons from yeasts. Curr Biol 2010, 20:R746-R753.

38. Baker CR, Booth LN, Sorrells TR, Johnson AD: Protein modularity, cooperative binding, and hybrid regulatory states underlie transcriptional network diversification. Cell 2012, 151:80-95.

39. 1000 fungal genome project. [http://1000.fungalgenomes.org/home/]

40. Edgar RC: MUSCLE: multiple sequence alignment with high accuracy and high throughput. Nucl Acids Res 2004, 32:1792-1797.

41. Tamura K, Dudley J, Nei M, Kumar S: MEGA4: molecular evolutionary genetics analysis (MEGA) software version 4.0. Mol Biol Evol 2007, 24:1596-1599.

42. Grigoriev IV, Cullen D, Goodwin SB, Hibbett D, Jeffries TW, Kubicek CP Kuske C, Magnuson JK, Martin F, Spatafora JW, Tsang A, Baker SE: Fueling the future with fungal genomics. Mycology 2011, 2:192-209.

43. Fungal genome initiative. [http://www.broadinstitute.org/scientific-community/ science/projects/fungal-genome-initiative/fungal-genome-initiative]

44. Arnaud MB, Chibucos MC, Costanzo MC, Crabtree J, Inglis DO, Lotia A, Orvis J, Shah P, Skrzypek MS, Binkley G, Miyasato SR, Wortman JR, Sherlock G: The Aspergillus Genome Database, a curated comparative genomics resource for gene, protein and sequence information for the Aspergillus research community. Nucl Acids Res 2010, 38:D420-D427.

45. Arnaud MB, Cerqueira GC, Inglis DO, Skrzypek MS, Binkley J, Chibucos MC, Crabtree J, Howarth C, Orvis J, Shah P, Wymore F, Binkley G, Miyasato SR, Simison M, Sherlock G, Wortman JR: The Aspergillus Genome Database (AspGD): recent developments in comprehensive multispecies curation, comparative genomics and community resources. Nucl Acids Res 2012, 40:D653-D659.

46. Benson DA, Cavanaugh M, Clark K, Karsch-Mizrachi I, Lipman DJ, Ostell J, Sayers EW: GenBank. Nucl Acids Res 2013, 41:D36-D42.

47. Finn RD, Mistry J, Tate J, Coggill P, Heger A, Pollington JE, Gavin OL, Gunasekaran P, Ceric G, Forslund K, Holm L, Sonnhammer EL, Eddy SR, Bateman A: The Pfam protein families database. Nucl Acids Res 2010, 38:D211-D222.

48. Eddy SR: Accelerated profile HMM searches. PLoS Comput Biol 2011, 7:e1002195.

49. Li L, Stoeckert CJ Jr, Roos DS: OrthoMCL: identification of ortholog groups for eukaryotic genomes. Genome Res 2003, 13:2178-2189.

50. Katoh K, Kuma K-i, Toh H, Miyata T: MAFFT version 5: improvement in accuracy of multiple sequence alignment. Nucl Acids Res 2005, 33:511-518.

51. Katoh $\mathrm{K}$, Asimenos $\mathrm{G}$, Toh H: Multiple alignment of DNA sequences with MAFFT. Methods Mol Biol 2009, 537:39-64.

52. Sturn A, Quackenbush J, Trajanoski Z: Genesis: cluster analysis of microarray data. Bioinformatics 2002, 18:207-208.

53. Todd RB, Zhao M, Ohm RA, Leeggangers HACF, Visser L, de Vries RP: Data from: Prevalence of transcription factors in ascomycete and basidiomycete fungi. Dryad Digital Repository 2014 [http://dx.doi.org/10.5061/dryad.3f5j9]

54. Ohm RA, Feau N, Henrissat B, Schoch CL, Horwitz BA, Barry KW, Condon BJ, Copeland AC, Dhillon B, Glaser F, Hesse CN, Kosti I, LaButti K, Lindquist EA, Lucas S, Salamov AA, Bradshaw RE, Ciuffetti L, Hamelin RC, Kema GH, Lawrence C, Scott JA, Spatafora JW, Turgeon BG, de Wit PJ, Zhong S, Goodwin SB, Grigoriev IV: Diverse lifestyles and strategies of plant pathogenesis encoded in the genomes of eighteen Dothideomycetes fungi. PLOS Pathog 2012, 8:e1003037.

55. de Wit PJ, van der Burgt A, Okmen B, Stergiopoulos I, Abd-Elsalam KA, Aerts AL, Bahkali AH, Beenen HG, Chettri P, Cox MP, Datema E, de Vries RP, Dhillon B, Ganley AR, Griffiths SA, Guo Y, Hamelin RC, Henrissat B, Kabir MS, Jashni MK, Kema G, Klaubauf S, Lapidus A, Levasseur A, Lindquist E, Mehrabi R, Ohm RA, Owen TJ, Salamov A, Schwelm A, et al: The genomes of the fungal plant pathogens Cladosporium fulvum and Dothistroma septosporum reveal adaptation to different hosts and lifestyles but also signatures of common ancestry. PLoS Genet 2012, 8:e1003088.

56. Goodwin SB, M'Barek SB, Dhillon B, Wittenberg AH, Crane CF, Hane JK, Foster AJ, van der Lee TA, Grimwood J, Aerts A, Antoniw J, Bailey A, Bluhm B, Bowler J, Bristow J, van der Burgt A, Canto-Canche B, Churchill AC, Conde-Ferraez L, Cools HJ, Coutinho PM, Csukai M, Dehal P, de Wit P, Donzelli B, van de Geest HC, van Ham RC, Hammond-Kosack KE, Henrissat B, 
Kilian A, et al: Finished genome of the fungal wheat pathogen Mycosphaerella graminicola reveals dispensome structure, chromosome plasticity, and stealth pathogenesis. PLOS Genet 2011, 7:e1002070.

57. Hane JK, Lowe RG, Solomon PS, Tan KC, Schoch CL, Spatafora JW, Crous PW, Kodira C, Birren BW, Galagan JE, Torriani SF, McDonald BA, Oliver RP: Dothideomycete plant interactions illuminated by genome sequencing and EST analysis of the wheat pathogen Stagonospora nodorum. Plant Cell 2007, 19:3347-3368.

58. Sharpton TJ, Stajich JE, Rounsley SD, Gardner MJ, Wortman JR, Jordar VS, Maiti R, Kodira CD, Neafsey DE, Zeng Q, Hung CY, McMahan C, Muszewska A, Grynberg M, Mandel MA, Kellner EM, Barker BM, Galgiani JN, Orbach MJ, Kirkland TN, Cole GT, Henn MR, Birren BW, Taylor JW: Comparative genomic analyses of the human fungal pathogens Coccidioides and their relatives. Genome Res 2009, 19:1722-1731.

59. Fedorova ND, Khaldi N, Joardar VS, Maiti R, Amedeo P, Anderson MJ, Crabtree J, Silva JC, Badger JH, Albarraq A, Angiuoli S, Bussey H, Bowyer P, Cotty PJ, Dyer PS, Egan A, Galens K, Fraser-Liggett CM, Haas BJ, Inman JM, Kent R, Lemieux S, Malavazi I, Orvis J, Roemer T, Ronning CM, Sundaram JP, Sutton G, Turner G, Venter JC, et al: Genomic islands in the pathogenic filamentous fungus Aspergillus fumigatus. PLoS Genet 2008, 4:e1000046.

60. Yu J, Payne GA, Nierman WC, Machida M, Bennett JW, Campbell BC, Robens JF, Bhatnagar D, Dean RA, Cleveland TE: Aspergillus flavus genomics as a tool for studying the mechanism of aflatoxin formation. Food Addit Contam Part A Chem Anal Control Expo Risk Assess 2008, 25:1152-1157.

61. Nierman WC, Pain A, Anderson MJ, Wortman JR, Kim HS, Arroyo J, Berriman M, Abe K, Archer DB, Bermejo C, Bennett J, Bowyer P, Chen D, Collins M, Coulsen R, Davies R, Dyer PS, Farman M, Fedorova N, Feldblyum TV, Fischer R, Fosker N, Fraser A, Garcia JL, Garcia MJ, Goble A, Goldman GH, Gomi K, Griffith-Jones S, Gwilliam R, et al: Genomic sequence of the pathogenic and allergenic filamentous fungus Aspergillus fumigatus. Nature 2005, 438:1151-1156.

62. Galagan JE, Calvo SE, Cuomo C, Ma LJ, Wortman JR, Batzoglou S, Lee SI, Basturkmen M, Spevak CC, Clutterbuck J, Kapitonov V, Jurka J, Scazzocchio C, Farman M, Butler J, Purcell S, Harris S, Braus GH, Draht O, Busch S, D'Enfert C, Bouchier C, Goldman GH, Bell-Pedersen D, Griffiths-Jones S, Doonan JH, Yu J, Vienken K, Pain A, Freitag M, et al: Sequencing of Aspergillus nidulans and comparative analysis with $A$. fumigatus and $A$. oryzae. Nature 2005, 438:1105-1115

63. Andersen MR, Salazar MP, Schaap PJ, van de Vondervoort PJ, Culley D, Thykaer J, Frisvad JC, Nielsen KF, Albang R, Albermann K, Berka RM, Braus GH, Braus-Stromeyer SA, Corrochano LM, Dai Z, van Dijck PW, Hofmann G, Lasure LL, Magnuson JK, Menke H, Meijer M, Meijer SL, Nielsen JB, Nielsen ML, van Ooyen AJ, Pel HJ, Poulsen L, Samson RA, Stam H, Tsang A, et al: Comparative genomics of citric-acid-producing Aspergillus niger ATCC 1015 versus enzyme-producing CBS 513.88. Genome Res 2011, 21:885-897.

64. Machida M, Asai K, Sano M, Tanaka T, Kumagai T, Terai G, Kusumoto K, Arima T, Akita O, Kashiwagi Y, Abe K, Gomi K, Horiuchi H, Kitamoto K, Kobayashi T, Takeuchi M, Denning DW, Galagan JE, Nierman WC, Yu J, Archer DB, Bennett JW, Bhatnagar D, Cleveland TE, Fedorova ND, Gotoh O, Horikawa H, Hosoyama A, Ichinomiya M, Igarashi $\mathrm{R}$, et al: Genome sequencing and analysis of Aspergillus oryzae. Nature 2005, 438:1157-1161.

65. van den Berg MA, Albang R, Albermann K, Badger JH, Daran JM, Driessen AJ, Garcia-Estrada C, Fedorova ND, Harris DM, Heijne WH, Joardar V, Kiel JA, Kovalchuk A, Martin JF, Nierman WC, Nijland JG, Pronk JT, Roubos JA, van der Klei IJ, van Peij NN, Veenhuis M, von Dohren H, Wagner C, Wortman J, Bovenberg RA: Genome sequencing and analysis of the filamentous fungus Penicillium chrysogenum. Nat Biotechnol 2008, 26:1161-1168.

66. Amselem J, Cuomo CA, van Kan JA, Viaud M, Benito EP, Couloux A, Coutinho PM, de Vries RP, Dyer PS, Fillinger S, Fournier E, Gout L, Hahn M, Kohn L, Lapalu N, Plummer KM, Pradier JM, Quevillon E, Sharon A, Simon A, ten Have A, Tudzynski B, Tudzynski P, Wincker P, Andrew M, Anthouard V, Beever RE, Beffa R, Benoit I, Bouzid O, et al: Genomic analysis of the necrotrophic fungal pathogens Sclerotinia sclerotiorum and Botrytis cinerea. PLoS Genet 2011, 7:e1002230.

67. Martin F, Kohler A, Murat C, Balestrini R, Coutinho PM, Jaillon O, Montanini B, Morin E, Noel B, Percudani R, Porcel B, Rubini A, Amicucci A, Amselem J, Anthouard V, Arcioni S, Artiguenave F, Aury JM, Ballario P, Bolchi A, Brenna A, Brun A, Buee M, Cantarel B, Chevalier G, Couloux A, da Silva C, Denoeud F, Duplessis S, Ghignone S, et al: Perigord black truffle genome uncovers evolutionary origins and mechanisms of symbiosis. Nature 2010, 464:1033-1038.
68. Maguire SL, OhEigeartaigh SS, Byrne KP, Schroder MS, O'Gaora P, Wolfe KH, Butler G: Comparative genome analysis and gene finding in Candida species using CGOB. Mol Biol Evol 2013, 30:1281-1291.

69. Dujon B, Sherman D, Fischer G, Durrens P, Casaregola S, Lafontaine I, de Montigny J, Marck C, Neuveglise C, Talla E, Goffard N, Frangeul L, Aigle M, Anthouard V, Babour A, Barbe V, Barnay S, Blanchin S, Beckerich JM, Beyne E, Bleykasten C, Boisrame A, Boyer J, Cattolico L, Confanioleri F, de Daruvar A, Despons L, Fabre E, Fairhead C, Ferry-Dumazet $H$, et al: Genome evolution in yeasts. Nature 2004, 430:35-44.

70. Piskur J, Ling Z, Marcet-Houben M, Ishchuk OP, Aerts A, LaButti K, Copeland A, Lindquist E, Barry K, Compagno C, Bisson L, Grigoriev IV, Gabaldon T, Phister T: The genome of wine yeast Dekkera bruxellensis provides a tool to explore its food-related properties. Int J Food Microbiol 2012, 157:202-209.

71. Brown SD, Klingeman DM, Johnson CM, Clum A, Aerts A, Salamov A, Sharma A, Zane M, Barry K, Grigoriev IV, Davison BH, Lynd LR, Gilna P, Hau $\mathrm{H}$, Hogsett DA, Froehlich AC: Genome sequences of industrially relevant Saccharomyces cerevisiae strain M3707, isolated from a sample of distillers yeast and four haploid derivatives. Genome Announc 2013, 1:e00313-e00323.

72. Giaever G, Chu AM, Ni L, Connelly C, Riles L, Veronneau S, Dow S, Lucau-Danila A, Anderson K, Andre B, Arkin AP, Astromoff A, El-Bakkoury M, Bangham R, Benito R, Brachat S, Campanaro S, Curtiss M, Davis K, Deutschbauer A, Entian KD, Flaherty P, Foury F, Garfinkel DJ, Gerstein M, Gotte D, Guldener U, Hegemann JH, Hempel S, Herman Z, et al: Functional profiling of the Saccharomyces cerevisiae genome. Nature 2002, 418:387-391.

73. Souciet JL, Dujon B, Gaillardin C, Johnston M, Baret PV, Cliften P, Sherman DJ, Weissenbach J, Westhof E, Wincker P, Jubin C, Poulain J, Barbe V, Segurens B, Artiguenave F, Anthouard V, Vacherie B, Val ME, Fulton RS, Minx P, Wilson R, Durrens P, Jean G, Marck C, Martin T, Nikolski M, Rolland T, Seret $M L$, Casaregola S, Despons L, et al: Comparative genomics of protoploid Saccharomycetaceae. Genome Res 2009, 19:1696-1709.

74. Rhind N, Chen Z, Yassour M, Thompson DA, Haas BJ, Habib N, Wapinski I, Roy S, Lin MF, Heiman DI, Young SK, Furuya K, Guo Y, Pidoux A, Chen HM, Robbertse B, Goldberg JM, Aoki K, Bayne EH, Berlin AM, Desjardins CA, Dobbs E, Dukaj L, Fan L, FitzGerald MG, French C, Gujja S, Hansen K, Keifenheim D, Levin JZ, et al: Comparative functional genomics of the fission yeasts. Science 2011, 332:930-936.

75. Chaetomium globosum sequencing project. [http://www.broadinstitute.org/ annotation/genome/chaetomium_globosum/]

76. Ma LJ, van der Does HC, Borkovich KA, Coleman JJ, Daboussi MJ, di Pietro A, Dufresne M, Freitag M, Grabherr M, Henrissat B, Houterman PM, Kang S, Shim WB, Woloshuk C, Xie X, Xu JR, Antoniw J, Baker SE, Bluhm BH, Breakspear A, Brown DW, Butchko RA, Chapman S, Coulson R, Coutinho PM, Danchin EG, Diener A, Gale LR, Gardiner DM, Goff S, et al: Comparative genomics reveals mobile pathogenicity chromosomes in Fusarium. Nature 2010, 464:367-373.

77. Cuomo CA, Guldener U, Xu JR, Trail F, Turgeon BG, di Pietro A, Walton JD, Ma LJ, Baker SE, Rep M, Adam G, Antoniw J, Baldwin T, Calvo S, Chang YL, Decaprio D, Gale LR, Gnerre S, Goswami RS, Hammond-Kosack K, Harris LJ, Hilburn K, Kennell JC, Kroken S, Magnuson JK, Mannhaupt G, Mauceli E, Mewes HW, Mitterbauer R, Muehlbauer G, et al: The Fusarium graminearum genome reveals a link between localized polymorphism and pathogen specialization. Science 2007, 317:1400-1402.

78. Dean RA, Talbot NJ, Ebbole DJ, Farman ML, Mitchell TK, Orbach MJ, Thon M, Kulkarni R, Xu JR, Pan H, Read ND, Lee YH, Carbone I, Brown D, Oh YY, Donofrio N, Jeong JS, Soanes DM, Djonovic S, Kolomiets E, Rehmeyer C, Li W, Harding M, Kim S, Lebrun MH, Bohnert H, Coughlan S, Butler J, Calvo S, $\mathrm{Ma} L$, et al: The genome sequence of the rice blast fungus Magnaporthe grisea. Nature 2005, 434:980-986.

79. Magnaporthe comparative sequencing project. [http://www.broadinstitute. org/annotation/genome/magnaporthe_comparative/MultiHome.html]

80. Berka RM, Grigoriev IV, Otillar R, Salamov A, Grimwood J, Reid I, Ishmael N, John T, Darmond C, Moisan MC, Henrissat B, Coutinho PM, Lombard V, Natvig DO, Lindquist E, Schmutz J, Lucas S, Harris P, Powlowski J, Bellemare A, Taylor D, Butler G, de Vries RP, Allijn IE, van den Brink J, Ushinsky S, Storms R, Powell AJ, Paulsen IT, Elbourne LD, et al: Comparative genomic analysis of the thermophilic biomass-degrading fungi Myceliophthora thermophila and Thielavia terrestris. Nat Biotechnol 2011, 29:922-927.

81. Coleman JJ, Rounsley SD, Rodriguez-Carres M, Kuo A, Wasmann CC, Grimwood J, Schmutz J, Taga M, White GJ, Zhou S, Schwartz DC, Freitag M, Ma L, Danchin EG, Henrissat B, Coutinho PM, Nelson DR, Straney D, Napoli CA, 
Barker BM, Gribskov M, Rep M, Kroken S, Molnar I, Rensing C, Kennell JC, Zamora J, Farman ML, Selker EU, Salamov A, et al: The genome of Nectria haematococca: contribution of supernumerary chromosomes to gene expansion. PLoS Genet 2009, 5:e1000618.

82. Galagan JE, Calvo SE, Borkovich KA, Selker EU, Read ND, Jaffe D, FitzHugh W, Ma LJ, Smirnov S, Purcell S, Rehman B, Elkins T, Engels R, Wang S, Nielsen CB, Butler J, Endrizzi M, Qui D, lanakiev P, Bell-Pedersen D, Nelson MA, Werner-Washburne M, Selitrennikoff CP, Kinsey JA, Braun EL, Zelter A, Schulte U, Kothe GO, Jedd G, Mewes W, et al: The genome sequence of the filamentous fungus Neurospora crassa. Nature 2003, 422:859-868.

83. Neurospora discreta genome project. [http://genome.jgi.doe.gov/Neudi1/ Neudi1.home.html]

84. Ellison CE, Stajich JE, Jacobson DJ, Natvig DO, Lapidus A, Foster B, Aerts A, Riley R, Lindquist EA, Grigoriev IV, Taylor JW: Massive changes in genome architecture accompany the transition to self-fertility in the filamentous fungus Neurospora tetrasperma. Genetics 2011, 189:55-69.

85. Espagne E, Lespinet O, Malagnac F, da Silva C, Jaillon O, Porcel BM, Couloux A, Aury JM, Segurens B, Poulain J, Anthouard V, Grossetete S, Khalili H, Coppin E, Dequard-Chablat M, Picard M, Contamine V, Arnaise S, Bourdais A, Berteaux-Lecellier V, Gautheret D, de Vries RP, Battaglia E, Coutinho PM, Danchin EG, Henrissat B, Khoury RE, Sainsard-Chanet A, Boivin A, Pinan-Lucarre $B$, et al: The genome sequence of the model ascomycete fungus Podospora anserina. Genome Biol 2008, 9:R77.

86. Kubicek CP, Herrera-Estrella A, Seidl-Seiboth V, Martinez DA, Druzhinina IS, Thon M, Zeilinger S, Casas-Flores S, Horwitz BA, Mukherjee PK, Mukherjee M, Kredics L, Alcaraz LD, Aerts A, Antal Z, Atanasova L, Cervantes-Badillo MG, Challacombe J, Chertkov O, McCluskey K, Coulpier F, Deshpande N, von Dohren H, Ebbole DJ, Esquivel-Naranjo EU, Fekete E, Flipphi M, Glaser F, Gomez-Rodriguez EY, Gruber S, et al: Comparative genome sequence analysis underscores mycoparasitism as the ancestral life style of Trichoderma. Genome Biol 2011, 12:R40.

87. Martinez D, Berka RM, Henrissat B, Saloheimo M, Arvas M, Baker SE, Chapman J, Chertkov O, Coutinho PM, Cullen D, Danchin EG, Grigoriev IV, Harris P, Jackson M, Kubicek CP, Han CS, Ho I, Larrondo LF, de Leon AL, Magnuson JK, Merino S, Misra M, Nelson B, Putnam N, Robbertse B, Salamov AA, Schmoll M, Terry A, Thayer N, Westerholm-Parvinen A, et al: Genome sequencing and analysis of the biomass-degrading fungus Trichoderma reesei (syn. Hypocrea jecorina). Nat Biotechnol 2008, 26:553-560.

88. Wood V, Gwilliam R, Rajandream MA, Lyne M, Lyne R, Stewart A, Sgouros J, Peat N, Hayles J, Baker S, Basham D, Bowman S, Brooks K, Brown D, Brown S, Chillingworth T, Churcher C, Collins M, Connor R, Cronin A, Davis P, Feltwell T, Fraser A, Gentles S, Goble A, Hamlin N, Harris D, Hidalgo J, Hodgson G, Holroyd $S$, et al: The genome sequence of Schizosaccharomyces pombe. Nature 2002, 415:871-880.

89. Morin E, Kohler A, Baker AR, Foulongne-Oriol M, Lombard V, Nagy LG, Ohm RA, Patyshakuliyeva A, Brun A, Aerts AL, Bailey AM, Billette C, Coutinho PM, Deakin G, Doddapaneni H, Floudas D, Grimwood J, Hilden K, Kues U, Labutti KM, Lapidus A, Lindquist EA, Lucas SM, Murat C, Riley RW, Salamov AA, Schmutz J, Subramanian V, Wosten HA, Xu J, et al: Genome sequence of the button mushroom Agaricus bisporus reveals mechanisms governing adaptation to a humic-rich ecological niche. Proc Natl Acad Sci USA 2012, 109:17501-17506.

90. Floudas D, Binder M, Riley R, Barry K, Blanchette RA, Henrissat B, Martinez AT, Otillar R, Spatafora JW, Yadav JS, Aerts A, Benoit I, Boyd A, Carlson A, Copeland A, Coutinho PM, de Vries RP, Ferreira P, Findley K, Foster B, Gaskell J, Glotzer D, Gorecki P, Heitman J, Hesse C, Hori C, Igarashi K, Jurgens JA, Kallen N, Kersten $P$, et al: The Paleozoic origin of enzymatic lignin decomposition reconstructed from 31 fungal genomes. Science 2012, 336:1715-1719.

91. Fernandez-Fueyo E, Ruiz-Duenas FJ, Ferreira P, Floudas D, Hibbett DS, Canessa P, Larrondo LF, James TY, Seelenfreund D, Lobos S, Polanco R, Tello M, Honda Y, Watanabe T, Ryu JS, Kubicek CP, Schmoll M, Gaskell J, Hammel KE, St John FJ, Vanden Wymelenberg A, Sabat G, Splinter BonDurant S, Syed K, Yadav JS, Doddapaneni H, Subramanian V, Lavin JL, Oguiza JA, Perez G, et al: Comparative genomics of Ceriporiopsis subvermispora and Phanerochaete chrysosporium provide insight into selective ligninolysis. Proc Natl Acad Sci USA 2012, 109:5458-5463.

92. Stajich JE, Wilke SK, Ahren D, Au CH, Birren BW, Borodovsky M, Burns C, Canback B, Casselton LA, Cheng CK, Deng J, Dietrich FS, Fargo DC, Farman ML, Gathman AC, Goldberg J, Guigo R, Hoegger PJ, Hooker JB, Huggins A, James TY, Kamada T, Kilaru S, Kodira C, Kues U, Kupfer D, Kwan HS,
Lomsadze A, Li W, Lilly WW, et al: Insights into evolution of multicellular fungi from the assembled chromosomes of the mushroom Coprinopsis cinerea (Coprinus cinereus). Proc Natl Acad Sci USA 2010, 107:11889-11894.

93. Abadio AK, Kioshima ES, Teixeira MM, Martins NF, Maigret B, Felipe MS: Comparative genomics allowed the identification of drug targets against human fungal pathogens. BMC Genomics 2011, 12:75.

94. Chen S, Xu J, Liu C, Zhu Y, Nelson DR, Zhou S, Li C, Wang L, Guo X, Sun Y, Luo H, Li Y, Song J, Henrissat B, Levasseur A, Qian J, Li J, Luo X, Shi L, He L, Xiang L, Xu X, Niu Y, Li Q, Han MV, Yan H, Zhang J, Chen H, Lv A, Wang Z, et al: Genome sequence of the model medicinal mushroom Ganoderma lucidum. Nat Commun 2012, 3:913.

95. Olson A, Aerts A, Asiegbu F, Belbahri L, Bouzid O, Broberg A, Canback B, Coutinho PM, Cullen D, Dalman K, Deflorio G, van Diepen LT, Dunand C, Duplessis S, Durling M, Gonthier P, Grimwood J, Fossdal CG, Hansson D, Henrissat B, Hietala A, Himmelstrand K, Hoffmeister D, Hogberg N, James TY, Karlsson M, Kohler A, Kues U, Lee YH, Lin YC, et al: Insight into trade-off between wood decay and parasitism from the genome of a fungal forest pathogen. New Phytol 2012, 194:1001-1013.

96. Martin F, Aerts A, Ahren D, Brun A, Danchin EG, Duchaussoy F, Gibon J, Kohler A, Lindquist E, Pereda V, Salamov A, Shapiro HJ, Wuyts J, Blaudez D, Buee M, Brokstein P, Canback B, Cohen D, Courty PE, Coutinho PM, Delaruelle C, Detter JC, Deveau A, DiFazio S, Duplessis S, Fraissinet-Tachet L, Lucic E, Frey-Klett P, Fourrey C, Feussner I, et al: The genome of Laccaria bicolor provides insights into mycorrhizal symbiosis. Nature 2008, 452:88-92.

97. Suzuki H, MacDonald J, Syed K, Salamov A, Hori C, Aerts A, Henrissat B, Wiebenga A, VanKuyk PA, Barry K, Lindquist E, LaButti K, Lapidus A, Lucas S, Coutinho P, Gong Y, Samejima M, Mahadevan R, Abou-Zaid M, de Vries RP, Igarashi K, Yadav JS, Grigoriev IV, Master ER: Comparative genomics of the white-rot fungi, Phanerochaete carnosa and $P$. chrysosporium, to elucidate the genetic basis of the distinct wood types they colonize. BMC Genomics 2012, 13:444.

98. Martinez D, Larrondo LF, Putnam N, Gelpke MD, Huang K, Chapman J, Helfenbein KG, Ramaiya P, Detter JC, Larimer F, Coutinho PM, Henrissat B, Berka R, Cullen D, Rokhsar D: Genome sequence of the lignocellulose degrading fungus Phanerochaete chrysosporium strain RP78. Nat Biotechnol 2004, 22:695-700.

99. Zuccaro A, Basiewicz M, Zurawska M, Biedenkopf D, Kogel KH: Karyotype analysis, genome organization, and stable genetic transformation of the root colonizing fungus Piriformospora indica. Fungal Genet Biol 2009, 46:543-550.

100. Ohm RA, de Jong JF, Lugones LG, Aerts A, Kothe E, Stajich JE, de Vries RP, Record E, Levasseur A, Baker SE, Bartholomew KA, Coutinho PM, Erdmann S, Fowler TJ, Gathman AC, Lombard V, Henrissat B, Knabe N, Kues U, Lilly WW, Lindquist E, Lucas S, Magnuson JK, Piumi F, Raudaskoski M, Salamov A, Schmutz J, Schwarze FW, Vankuyk PA, Horton JS, et al: Genome sequence of the model mushroom Schizophyllum commune. Nat Biotechnol 2010 28:957-963.

101. Eastwood DC, Floudas D, Binder M, Majcherczyk A, Schneider P, Aerts A, Asiegbu FO, Baker SE, Barry K, Bendiksby M, Blumentritt M, Coutinho PM, Cullen D, de Vries RP, Gathman A, Goodell B, Henrissat B, Ihrmark K, Kauserud H, Kohler A, LaButti K, Lapidus A, Lavin JL, Lee YH, Lindquist E, Lilly W, Lucas S, Morin E, Murat C, Oguiza JA, et al: The plant cell wall-decomposing machinery underlies the functional diversity of forest fungi. Science 2011, 333:762-765.

102. Gillece JD, Schupp JM, Balajee SA, Harris J, Pearson T, Yan Y, Keim P, DeBess E, Marsden-Haug N, Wohrle R, Engelthaler DM, Lockhart SR: Whole genome sequence analysis of Cryptococcus gattii from the Pacific Northwest reveals unexpected diversity. PLoS One 2011, 6:e28550.

103. Xu J, Saunders CW, Hu P, Grant RA, Boekhout T, Kuramae EE, Kronstad JW, Deangelis YM, Reeder NL, Johnstone KR, Leland M, Fieno AM, Begley WM, Sun Y, Lacey MP, Chaudhary T, Keough T, Chu L, Sears R, Yuan B, Dawson TL Jr: Dandruff-associated Malassezia genomes reveal convergent and divergent virulence traits shared with plant and human fungal pathogens. Proc Natl Acad Sci USA 2007, 104:18730-18735.

104. Kamper J, Kahmann R, Bolker M, Ma LJ, Brefort T, Saville BJ, Banuett F, Kronstad JW, Gold SE, Muller O, Perlin MH, Wosten HA, de Vries R, Ruiz-Herrera J, Reynaga-Pena CG, Snetselaar K, McCann M, Perez-Martin J, Feldbrugge M, Basse CW, Steinberg G, Ibeas Jl, Holloman W, Guzman P, Farman M, Stajich JE, Sentandreu R, Gonzalez-Prieto JM, Kennell JC, Molina $L$, et al: Insights from the genome of the biotrophic fungal plant pathogen Ustilago maydis. Nature 2006, 444:97-101. 
105. Han S, Adams TH: Complex control of the developmental regulatory locus brlA in Aspergillus nidulans. Mol Genet Genomics 2001, 266:260-270.

106. Ohm RA, Jong de JF, Bekker de C, Wösten HAB, Lugones LG: Transcription factor genes of Schizophyllum commune involved in regulation of mushroom formation. Mol Microbiol 2011, 81:1433-1445.

107. Odenbach D, Breth B, Thines E, Weber RW, Anke H, Foster AJ: The transcription factor Con7p is a central regulator of infection-related morphogenesis in the rice blast fungus Magnaporthe grisea. Mol Microbiol 2007, 64:293-307.

108. Tuncher A, Reinke H, Martic G, Caruso ML, Brakhage AA: A basic-region helix-loop-helix protein-encoding gene $(\operatorname{dev} R)$ involved in the development of Aspergillus nidulans. Mol Microbiol 2004, 52:227-241.

109. Pascon RC, Miller BL: Morphogenesis in Aspergillus nidulans requires Dopey (DopA), a member of a novel family of leucine zipper-like proteins conserved from yeast to humans. Mol Microbiol 2000, 36:1250-1264.

110. Wieser J, Adams TH: flbD encodes a Myb-like DNA-binding protein that coordinates initiation of Aspergillus nidulans conidiophore development. Genes Dev 1995, 9:491-502

111. Reverberi M, Fabbri AA, Zjalic S, Ricelli A, Punelli F, Fanelli C: Antioxidant enzymes stimulation in Aspergillus parasiticus by Lentinula edodes inhibits aflatoxin production. Appl Microbiol Biotechnol 2005, 69:207-215.

112. Busby TM, Miller KY, Miller BL: Suppression and enhancement of the Aspergillus nidulans medusa mutation by altered dosage of the bristle and stunted genes. Genetics 1996, 143:155-163.

113. Han KH, Han KY, Yu JH, Chae KS, Jahng KY, Han DM: The nsdD gene encodes a putative GATA-type transcription factor necessary for sexual development of Aspergillus nidulans. Mol Microbiol 2001, 41:299-309.

114. Damveld RA, Arentshorst M, Franken A, vanKuyk PA, Klis FM, van den Hondel CA, Ram AF: The Aspergillus niger MADS-box transcription factor $\mathrm{RImA}$ is required for cell wall reinforcement in response to cell wall stress. Mol Microbiol 2005, 58:305-319.

115. Vienken K, Scherer M, Fischer R: The Zn(II)2Cys6 putative Aspergillus nidulans transcription factor repressor of sexual development inhibits sexual development under low-carbon conditions and in submersed culture. Genetics 2005, 169:619-630.

116. Vallim MA, Miller KY, Miller BL: Aspergillus SteA (sterile12-like) is a homeodomain- $\mathrm{C} 2 / \mathrm{H} 2-\mathrm{Zn}^{+2}$ finger transcription factor required for sexual reproduction. Mol Microbiol 2000, 36:290-301.

117. Miller KY, Toennis TM, Adams TH, Miller BL: Isolation and transcriptional characterization of a morphological modifier: the Aspergillus nidulans stunted (stuA) gene. Mol Gen Genet 1991, 227:285-292

118. Kim H, Han K, Kim K, Han D, Jahng K, Chae K: The veA gene activates sexual development in Aspergillus nidulans. Fungal Genet Biol 2002, 37:72-80.

119. Ohm RA, Aerts D, Wosten HA, Lugones LG: The blue light receptor complex WC-1/2 of Schizophyllum commune is involved in mushroom formation and protection against phototoxicity. Environ Microbiol 2013, 15:943-955.

120. Aro N, Saloheimo M, Ilmén M, Penttilä M: ACEl, of Trichoderma reesei is a repressor of cellulase and xylanase expression. Appl Environ Microbiol 2003, 69:56-65.

121. Lockington R, Scazzocchio C, Sequeval D, Mathieu M, Felenbok B: Regulation of $a l c R$, the positive regulatory gene of the ethanol utilization regulon of Aspergillus nidulans. Mol Microbiol 1987, 1:275-281.

122. Lints R, Davis MA, Hynes MJ: The positively acting amdA gene of Aspergillus nidulans encodes a protein with two $\mathrm{C} 2 \mathrm{H} 2$ zinc-finger motifs. Mol Microbiol 1995, 15:965-975

123. Murphy RL, Andrianopoulos A, Davis MA, Hynes MJ: Identification of amdX, a new Cys-2-His-2 ( $\mathrm{C} 2 \mathrm{H} 2)$ zinc-finger gene involved in the regulation of the amdS gene of Aspergillus nidulans. Mol Microbiol 1997, 23:591-602.

124. Petersen KL, Lehmbeck J, Christensen T: A new transcriptional activator for amylase genes in Aspergillus. Mol Gen Genet 1999, 262:668-676.

125. Dowzer CEA, Kelly JM: Analysis of the creA gene, a regulator of carbon ca'olite repression in Aspergillus nidulans. Mol Cell Biol 1991, 11:5701-5709.

126. Todd RB, Murphy RL, Martin HM, Sharp JA, Davis MA, Katz ME, Hynes MJ: The acetate regulatory gene $f a c B$ of Aspergillus nidulans encodes a Zn(II)2Cys6 transcriptional activator. Mol Gen Genet 1997, 254:495-504.

127. Yuan XL, Roubos JA, van den Hondel CA, Ram AF: Identification of InuR, a new $\mathrm{Zn}$ (II)2Cys6 transcriptional activator involved in the regulation of inulinolytic genes in Aspergillus niger. Mol Genet Genomics 2008, 279:11-26.

128. Nehlin JO, Ronne H: Yeast MIG1 repressor is related to the mammalian early growth response and Wilms' tumour finger proteins. EMBO J 1990, 9:2891-2898.
129. Beri RK, Whittington $H$, Roberts $C F$, Hawkins AR: Isolation and characterization of the positively acting regulatory gene qutA from Aspergillus nidulans. Nucl Acids Res 1987, 15:7991-8001.

130. Gruben BS: Novel transcriptional activators of Aspergillus involved in plant biomass utilization. In PhD Thesis. Utrecht, The Netherlands: Utrecht University, Microbiology; 2012.

131. van Peij NN, Visser J, de Graaff LH: Isolation and analysis of $x \ln R$, encoding a transcriptional activator co-ordinating xylanolytic expression in Aspergillus niger. Mol Microbiol 1998, 27:131-142.

132. Andrianopoulos A, Hynes MJ: Sequence and functional analysis of the positively acting regulatory gene amdR from Aspergillus nidulans. Mol Cell Biol 1990, 10:3194-3203.

133. Caddick MX, Arst HN Jr, Taylor LH, Johnson RI, Brownlee AG: Cloning of the regulatory gene are $A$ mediating nitrogen metabolite repression in Aspergillus nidulans. EMBO J 1986, 5:1087-1090.

134. Conlon H, Zadra I, Haas H, Arst HN Jr, Jones MG, Caddick MX: The Aspergillus nidulans GATA transcription factor gene areB encodes at least three proteins and features three classes of mutation. Mol Microbiol 2001, 40:361-375.

135. Messenguy F, Dubois E, Descamps F: Nucleotide sequence of the ARGRII regulatory gene and amino acid sequence homologies between ARGRII PPRI and GAL4 regulatory proteins. Eur J Biochem 1986, 157:77-81.

136. Hoffmann B, Valerius O, Andermann M, Braus GH: Transcriptional autoregulation and inhibition of mRNA translation of amino acid regulator gene $c p c A$ of filamentous fungus Aspergillus nidulans. $\mathrm{Mol} B i \mathrm{O}$ Cell 2001, 12:2846-2857.

137. Polotnianka R, Monahan BJ, Hynes MJ, Davis MA: TamA interacts with LeuB, the homologue of Saccharomyces cerevisiae Leu3p, to regulate gdhA expression in Aspergillus nidulans. Mol Genet Genomics 2004, 272:452-459.

138. Polley SD, Caddick MX: Molecular characterisation of meaB, a novel gene affecting nitrogen metabolite repression in Aspergillus nidulans. FEBS Lett 1996, 388:200-205

139. Burger G, Strauss J, Scazzocchio C, Lang BF: nirA, the pathway-specific regulatory gene of nitrate assimilation in Aspergillus nidulans, encodes a putative GAL4-type zinc finger protein and contains four introns in highly conserved regions. Mol Cell Biol 1991, 11:5746-5755.

140. Andrianopoulos A, Kourambas S, Sharp JA, Davis MA, Hynes MJ: Characterization of the Aspergillus nidulans nmrA gene involved in nitrogen metabolite repression. J Bacteriol 1998, 180:1973-1977.

141. Froeliger EH, Carpenter BE: NUT1, a major nitrogen regulatory gene in Magnaporthe grisea, is dispensable for pathogenicity. Mol Gen Genet 1996, 251:647-656.

142. Cazelle B, Pokorska A, Hull E, Green PM, Stanway G, Scazzocchio C: Sequence, exon-intron organization, transcription and mutational analysis of $p r n A$, the gene encoding the transcriptional activator of the prn cluster in Aspergillus nidulans. Mol Microbiol 1998, 28:355-370.

143. Small AJ, Todd RB, Zanker MC, Delimitrou S, Hynes MJ, Davis MA: Functional analysis of TamA, a coactivator of nitrogen-regulated gene expression in Aspergillus nidulans. Mol Genet Genomics 2001, 265:636-646.

144. Suarez T, de Queiroz MV, Oestreicher N, Scazzocchio C: The sequence and binding specificity of UaY, the specific regulator of the purine utilization pathway in Aspergillus nidulans, suggest an evolutionary relationship with the PPR1 protein of Saccharomyces cerevisiae. EMBO J 1995, 14:1453-1467.

145. Woloshuk CP, Foutz KR, Brewer JF, Bhatnagar D, Cleveland TE, Payne GA: Molecular characterization of aflR, a regulatory locus for aflatoxin biosynthesis. Appl Environ Microbiol 1994, 60:2408-2414.

146. Mulder HJ, Nikolaev I, Madrid SM: HACA, the transcriptional activator of the unfolded protein response (UPR) in Aspergillus niger, binds to partly palindromic UPR elements of the consensus sequence $5^{\prime}-\mathrm{CAN}(\mathrm{G} / \mathrm{A})$ NTGT/GCCT-3'. Fungal Genet Biol 2006, 43:560-572.

147. Steidl S, Papagiannopoulos P, Litzka O, Andrianopoulos A, Davis MA Brakhage AA, Hynes MJ: AnCF, the CCAAT binding complex of Aspergillus nidulans, contains products of the $h a p B, h a p C$, and hapE genes and is required for activation by the pathway-specific regulatory gene $a m d R$. Mol Cell Biol 1999, 19:99-106.

148. Natorff R, Sienko M, Brzywczy J, Paszewski A: The Aspergillus nidulans metR gene encodes a bZIP protein which activates transcription of sulphur metabolism genes. Mol Microbiol 2003, 49:1081-1094.

149. Tilburn J, Sarkar S, Widdick DA, Espeso EA, Orejas M, Mungroo J, Penalva MA, Arst HN Jr: The Aspergillus PacC zinc finger transcription factor 
mediates regulation of both acid- and alkaline-expressed genes by ambient pH. EMBO J 1995, 14:779-790.

150. Caruso ML, Litzka O, Martic G, Lottspeich F, Brakhage AA: Novel basicregion helix-loop-helix transcription factor ( $\mathrm{AnBH} 1)$ of Aspergillus nidulans counteracts the CCAAT-binding complex AnCF in the promoter of a penicillin biosynthesis gene. J Mol Biol 2002, 323:425-439.

151. Haas H, Zadra I, Stoffler G, Angermayr K: The Aspergillus nidulans GATA factor SREA is involved in regulation of siderophore biosynthesis and control of iron uptake. J Biol Chem 1999, 274:4613-4619.

152. Hagiwara D, Asano Y, Marui J, Furukawa K, Kanamaru K, Kato M, Abe K, Kobayashi T, Yamashino T, Mizuno T: The SskA and SrrA response regulators are implicated in oxidative stress responses of hyphae and asexual spores in the phosphorelay signaling network of Aspergillus nidulans. Biosci Biotechnol Biochem 2007, 71:1003-1014.

Cite this article as: Todd et al: Prevalence of transcription factors in ascomycete and basidiomycete fungi. BMC Genomics 2014 15:214.

\section{Submit your next manuscript to BioMed Central and take full advantage of:}

- Convenient online submission

- Thorough peer review

- No space constraints or color figure charges

- Immediate publication on acceptance

- Inclusion in PubMed, CAS, Scopus and Google Scholar

- Research which is freely available for redistribution 